\title{
Theme of Humor and Advertising Effectiveness on Indonesian Children's Screens
}

\author{
Naldo $^{1 *}$, Sri Rahayu ${ }^{1}$, Hardika Widi Satria ${ }^{1}$ \\ ${ }^{1}$ Social and humanities Department, Communication - Advertising Studies, Vocational Education Program, Universitas Indonesia \\ *Email: naldomsi@gmail.com
}

\begin{abstract}
Humor is of value as a means of communication in a broad sense. Although humor often appears in advertisements, researchers tend to treat humor for advertising effectiveness to explore the use of humor-based advertising appeal in advertisements aimed at Indonesian children. The author conducted a systematic review and synthesis of humor in advertising on elementary school children. The research framework highlights the need to focus on the theme of humor. Research propositions are developed to guide further research on humor in advertising effectiveness.
\end{abstract}

Keywords: humor, advertising effectiveness

\section{Introduction}

The use of humor in most advertising continues to increase (Beard, 2008; Weinberger et al., 1995). Its complex nature is somehow believed to be effective in attracting the attention of its target audience (Sternthal and Craig, 1973). Although previous studies have defined the mechanism, types, and relatedness of humor in advertising, a complete understanding of the relationship between humor and consumer behavior is still arguable (Beard, 2008; Eisend, 2009).

Currently, some advertising in Indonesia includes the element of humor as part of the appeal, mostly in advertising that is addressed to children, that includes sweets, milk and chocolate. The elements in every advertisement usually have the same theme; they will use some animation, or a special character who invites the attention of the audience, especially elementary school children aged 7-12 years. This accords with previous literature that argued that humorous content refers to its subject or theme irrespective of the humor mechanism, which includes the following elements: visual and audio, spokesperson, brand and product, and core promotional messages. (Crawford and Gregory, 2015).

Humor is one of the most commonly used emotional appeals in global advertising (Koudelova and Whitelock, 2001; Hanna et al., 1994; Biswas et al., 1992), Most of these studies have been concerned mainly with TV advertising, and moreover, they have focused on the operational use of humorous ads, employing mainly Kelly and Solomon's technique typology (pun, understatement, joke, ludicrous, satire and irony) (1975) (Koudelova and Whitelock, 2001; Toncar, 2001; Alden and Martin, 1995; Biswas et al., 1992; Weinberger and Spotts, 1989).

Advertising has become a part of people's everyday lives. If you turn on the television there are ads, if you read the newspaper there are ads, the ad has even penetrated into the digital world. Of course, the advancement of the advertising industry has made the advertisers compete for the attention of a growing audience. One strategy to steal the attention is to include the element of humor in the content of their ads. Humorous ads can easily get circulated among friends, family and colleagues. Humor is popular in many countries; humorous television commercials have established seven categories of humor: slapstick, clownish humor, surprise, misunderstanding, irony, satire, and parody (Venkatesh and Senthilkumar, 2015).

The Indonesian government, over time, has arranged ads for children. TV ads for children are concentrated in a limited time according to the audience. The majority of children's impressions are available in the main program with special advertising features in the digital process on the Internet. There is a special pattern in digital literacy to know the audience of children in the display of ads on the Internet. Advertisers take cues and patterns of behavior from adults which makes them respond to ads that are pre-ordered for children.

\section{Method}

This research uses the quantitative research method with survey data collecting technique. The respondents of this research are 720 children aged from 7 to 12 years old, studying in public and private elementary schools in Greater Jakarta. Data collected is processed with SPSS using simple regression to establish the relationship between the theme of humor and advertising effectiveness. The distribution of questionnaires is conducted in 
two stages. The first stage is a screening questionnaire to find out the demographics of the respondents, and the second question is about the type of humor and the theme of humor.

In the process of completing the questionnaires, students are on hand to help the school-aged children in understanding it. The respondents are 360 children from public elementary schools and 360 children from private elementary schools in the Greater Jakarta area. The target respondents are elementary school children aged 7-12 years spread from grade 1 to grade 6 using non-probability sampling technique.

\section{Dependent Variable Independent Variable}

\begin{tabular}{|c|c|}
\hline $\begin{array}{c}\text { The Theme of } \\
\text { Humor }\end{array}$ & $\begin{array}{c}\text { The Advertising } \\
\text { Effectiveness }\end{array}$ \\
\hline
\end{tabular}

Fig. 1. Research Framework

\section{Results and Discussion}

The distribution of the questionnaire can be achieved of 1055 respondents' data with an almost even span of age but slightly dominated by the age of 9 years of $23 \%$ of the sample population. By gender girls slightly outnumber boys, with $52 \%$ girls and $49 \%$ boys (Fig. 2.).

Distribution of questionnaires and sample selection was divided equally between public elementary and private elementary schools in Greater Jakarta. The data can be seen in the chart of 1055 respondents that $51 \%$ of respondents attend private elementary schools and $49 \%$ are in public elementary schools. Of the total 1055, the majority of respondents live in Depok and Jakarta (Fig. 3.).
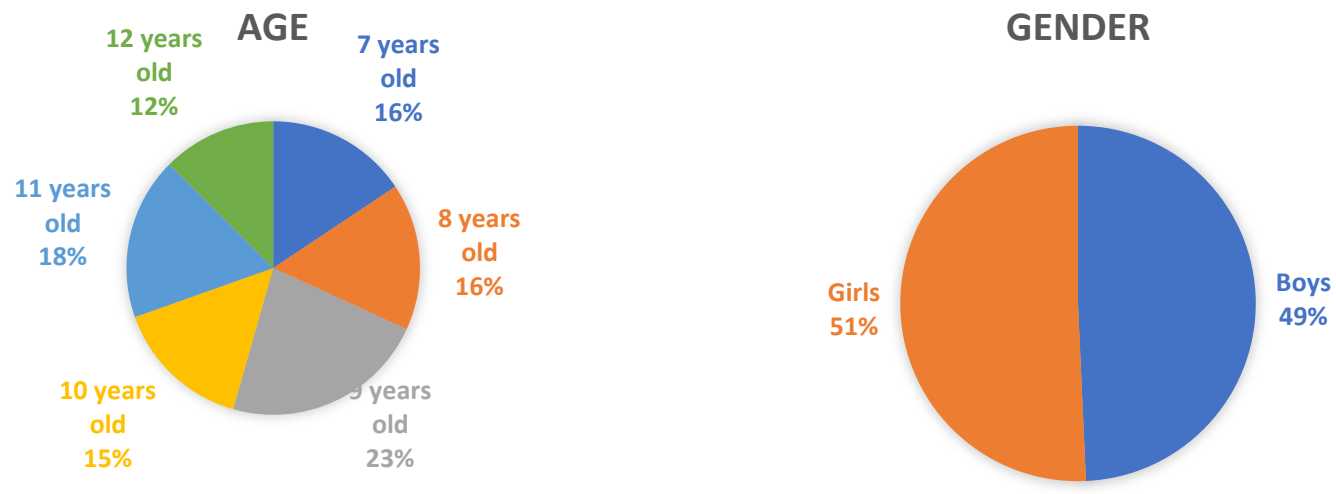

Fig. 2. Age and Gender Statistics Profile

The results of the questionnaires revealed that $48.4 \%$ of elementary school children aged from 7 to 12 years old earned pocket money from parents and 33.4\% obtained pocket money and were provided with food from home by their parents. The allowance spent by elementary school children is mostly spent on chocolate at $27 \%$, $24 \%$ on milk, and $23 \%$ on candy. The average amount of pocket money is between Rp 5,000 and Rp 10,000 is

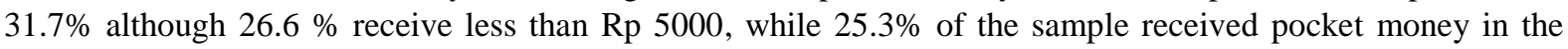
range of Rp 10,000-15,000 (Fig. 3). 


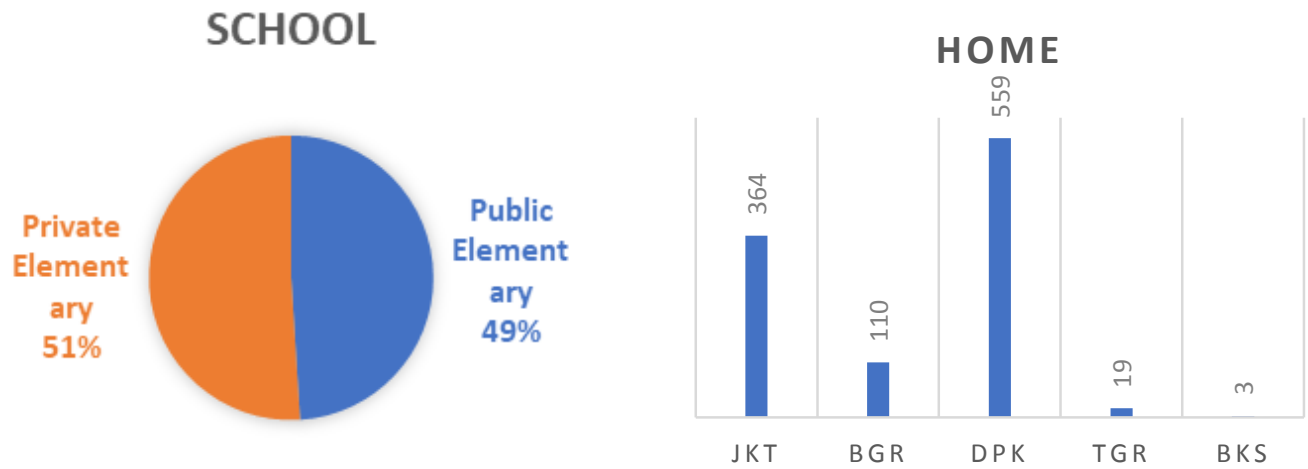

Fig. 3. School and Home Statistics Profile

HABIT

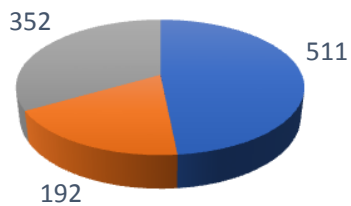

- Pocket Money $\square$ Bring Food from Home Both

\section{SPEND ON POCKET MONEY}

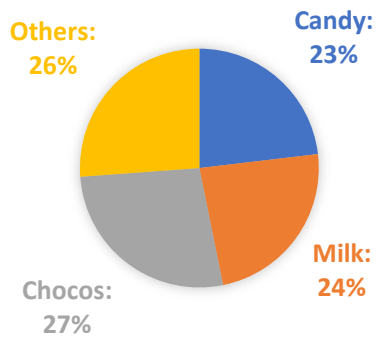

AMOUNT OF DAILY POCKET MONEY (IDR)

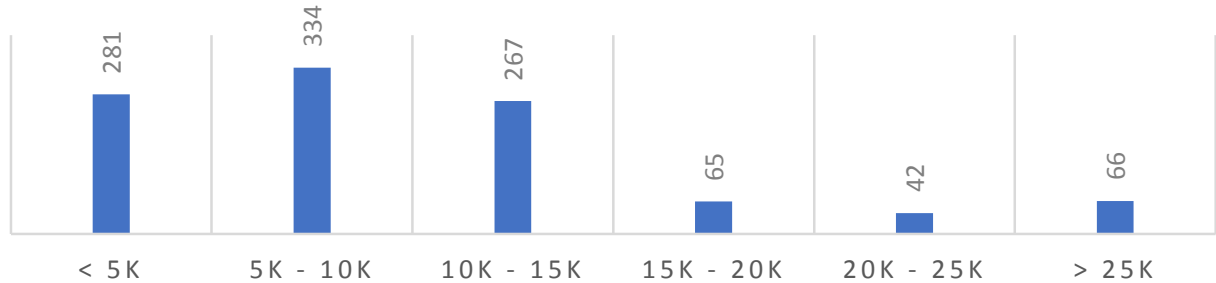

Fig. 4. Children's Pocket Money Statistics Profile

Nowadays, the majority (82\%) of elementary school children from 7 to 12 years old have their own Smartphone. Through gadgets, 66\% of elementary school children are exposed to advertising on YouTube. In one day $28.8 \%$ of elementary school children spend between 30 and 60 minutes playing with their gadgets. In fact, $15.6 \%$ of the sample report spending more than three hours playing with gadgets.

\section{TYPE OF GADGET}

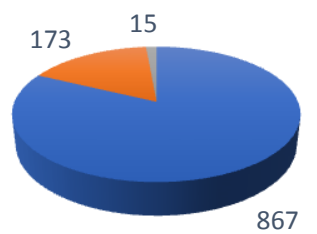

- Smartphone Tab Notebook

\section{YOUTUBE PREFERENCES}

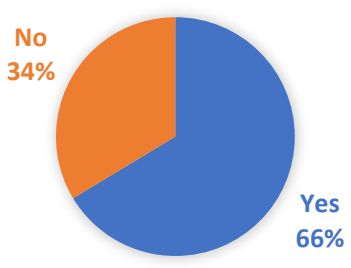


TIME SPENT ON GADGET

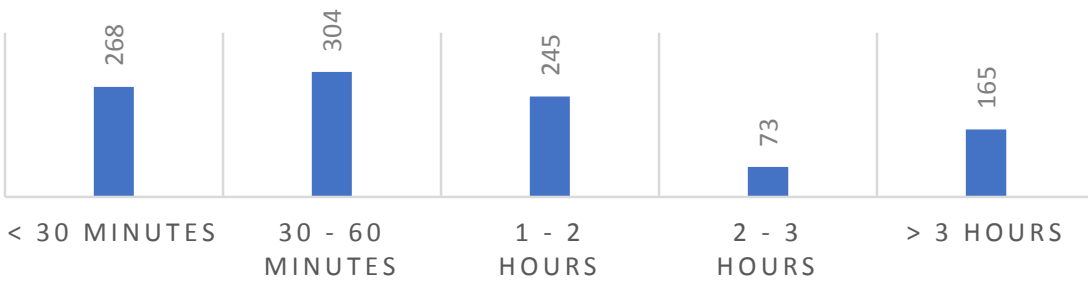

Fig. 5. Children's Gadget Use Statistics Profile

Table 1. Regression Analysis

\begin{tabular}{|c|c|c|c|c|c|c|c|c|c|c|}
\hline \multicolumn{11}{|c|}{ Model Summary } \\
\hline \multirow[b]{2}{*}{${ }_{\text {el }}^{\text {Mod }}$} & \multirow[b]{2}{*}{$\mathrm{R}$} & \multirow[b]{2}{*}{$\begin{array}{c}\mathrm{R} \\
\text { Square }\end{array}$} & & \multirow{2}{*}{\begin{tabular}{|l|}
\multicolumn{1}{c|}{ Std. } \\
Error of \\
the \\
Estimate
\end{tabular}} & \multicolumn{6}{|c|}{ Change Statistics } \\
\hline & & & \begin{tabular}{|rr} 
& Adjuste \\
d & $\mathrm{R}$ \\
Square & \\
\end{tabular} & & \begin{tabular}{l}
\multicolumn{1}{c}{$\mathrm{R}$} \\
Square \\
Change
\end{tabular} & \multicolumn{2}{|c|}{$\mathrm{F}$} & $\mathrm{d}$ & df 2 & $\begin{array}{r}\text { Sig. F } \\
\text { Change }\end{array}$ \\
\hline 1 & $.630^{\mathrm{a}}$ & .397 & .396 & .45205 & .397 & & 0.8 & 1 & 1051 & .000 \\
\hline \multicolumn{11}{|c|}{ a. Predictors: (Constant), Theme_of_Humor } \\
\hline \multicolumn{11}{|c|}{ ANOVA $^{\mathrm{a}}$} \\
\hline \multirow{4}{*}{$\begin{array}{l}\text { Mode } \\
1\end{array}$} & \multicolumn{3}{|c|}{$\begin{array}{r}\text { Sum } \\
\text { Squares }\end{array}$} & df & \multicolumn{2}{|c|}{ Mean Square } & \multicolumn{2}{|l|}{$\mathrm{F}$} & \multicolumn{2}{|l|}{ Sig. } \\
\hline & Regression & \multicolumn{2}{|c|}{141.183} & 1 & \multicolumn{2}{|c|}{141.183} & \multicolumn{2}{|c|}{690.890} & \multicolumn{2}{|c|}{$.000^{\mathrm{b}}$} \\
\hline & Residual & \multirow{2}{*}{\multicolumn{2}{|c|}{214.771}} & 1051 & \multicolumn{2}{|l|}{.204} & & & & \\
\hline & Total & & & 1052 & & & & & & \\
\hline \multicolumn{11}{|c|}{$\begin{array}{l}\text { a. Dependent Variable: Ads Effectiveness } \\
\text { b. Predictors: (Constant), Theme_of_Humor }\end{array}$} \\
\hline \multicolumn{11}{|c|}{ Coefficients $^{\text {a }}$} \\
\hline \multirow{2}{*}{\multicolumn{2}{|c|}{ Model }} & & \multicolumn{4}{|c|}{$\begin{array}{l}\text { Standardized } \\
\text { Coefficients } \\
\end{array}$} & & \\
\hline & & \multicolumn{3}{|c|}{\begin{tabular}{l|c}
\multicolumn{2}{l}{ Unstandardized Coefficients } \\
B & Std. Error
\end{tabular}} & \multicolumn{4}{|l|}{ Beta } & $\mathrm{T}$ & Sig. \\
\hline \multirow[t]{2}{*}{1} & (Constant) & .905 & .044 & & & & & & $25^{20.7}$ & .000 \\
\hline & $\begin{array}{l}\text { Theme of } \\
\text { Humor }\end{array}$ & .540 & .021 & & .630 & & & & $85^{26.2}$ & .000 \\
\hline
\end{tabular}

Based on the above results obtained figures, beta $(\beta)=0.630$ with a significance value $0.000<0.05$ so that $\mathrm{HO}$ is rejected, so it can be concluded that the relationship between the two variables is very significant and $\mathrm{H} 1$ is accepted or there is a relationship between the angle of theme of humor $(\mathrm{X})$ and advertising effectiveness (Y).

While the value of the number of betas $(\beta)$ is 0.630 (being in the range 0.10 to 0.630 ), it can be concluded that the relationship between scores runway theme of humor (X) and advertising effectiveness (Y) is weak. Standardized coefficients are positive $(+)$, which means that there is a tendency in the direction of the relationship if the foundation of the theme of humor (X) produces advertising effectiveness (Y), which is good. In other words, the higher the cornerstone of the theme of humor $(\mathrm{X})$ the higher is the advertising effectiveness (Y).

The results of the data show a significant influence, but $\mathrm{R}$ square between the influence of humor on the effectiveness of ads is only worth $39.6 \%$ for the elementary school children. It can be said that the foundation of a well-known theme of humor, in general, does influence advertising effectiveness itself, although the effect is weak.

\section{Conclusions}

In statistical tests, the results of the research will be obtained in a significant hypothesis or not. Significant understanding of research is the level of confidence by which a hypothesis is accepted or rejected. The level of 
statistical significance is expressed as a percentage indicating the risk of error in the test results produced. The significance level used by researchers is $5 \%(0.05)$, indicating that the smaller the level of significance, the smaller the chance of error from the test results performed.

From these results, it can be concluded that the effectiveness of advertisements in the digital era has now been equipped with a variety of humor, such as visual and audio, spokesperson, brand and product, and core promotional messages. Promotional messages that are suitable for children are advertisements that have humorous shades like cartoon characters or funny characters, joking and followed by fun music.

\section{Acknowledgments}

The author wish to thank Advertising Laboratory of Communication Studies of Vocational Education Program Universitas Indonesia, the students of communication - advertising year 2017, for the time, space, and valuable assistance during data collection. Also this research will not be realized without the help of God and Dr. Sri rahayu, S.E., M.S.M., and Prof. Dr. Ir. Sigit Pranowo Hadiwardoyo, DEA.

\section{References}

Barbara B. Stern, (1996) "Advertising comedy in electronic drama: The construct, theory and taxonomy", European Journal of Marketing, Vol. 30 Issue: 9, pp.37-59,

Douglas L. Fugate, (1998) "The advertising of services: what is an appropriate role for humor?", Journal of Services Marketing, Vol. 12 Issue: 6, pp.453-472,

Heather J. Crawford a, Gary D. Gregory (2015) Heather J. Crawford a, Gary D. Gregory" Journal of Business Research 68 pp.569-575,

Jill Kurp Maher, John B. Lord, Renée Shaw Hughner, Nancy M. Childs, (2006) "Food advertising on children's television", Young Consumers, Vol. 7 Issue: 4, pp.41-52,

Joshua D. Newton, Jimmy Wong, Fiona Joy Newton, (2016) "Listerine - for the bridesmaid who's never a bride: Disparaging humour increases brand attitude and recall among the powerless", European Journal of Marketing, Vol. 50 Issue: 7/8, pp.1137-1158,

Kapil Khandeparkar, Abhishek, (2017) "Influence of media context on humorous advertising effectiveness", Marketing Intelligence \& Planning, Vol. 35 Issue: 2, pp.259-276,

Leonidas Hatzithomas, Yorgos Zotos, Christina Boutsouki, (2011) "Humor and cultural values in print advertising: a crosscultural study," International Marketing Review, Vol. 28 Issue: 1, pp.57-80,

Malte Brettel, Andrea Spilker-Attig, (2010) "Online advertising effectiveness: a cross-cultural comparison," Journal of Research in Interactive Marketing, Vol. 4 Issue: 3, pp.176-196,

Nathalie Spielmann, (2014) "How funny was that? Uncovering humor mechanisms", European Journal of Marketing, Vol. 48 Issue: 9/10, pp.1892-1910,

Patrick Mirandah, (2006) "Advertising to children in Malaysia", Young Consumers, Vol. 7 Issue: 1, pp.74-76,

Rosemary Duff, (2004) "What advertising means to children", Young Consumers, Vol. 5 Issue: 2, pp.41-50,

Venkatesh S and Senthilkumar N (2015) "Effectiveness of humor advertising on advertising success", MPRA Paper No. 63973, posted 1. May 2015 05:24 UTC

Yong Zhang, James P. Neelankavil, (1997) "The influence of culture on advertising effectiveness in China and the USA: A cross-cultural study", European Journal of Marketing, Vol. 31 Issue: 2, pp.134-149, 